\title{
PERANCANGAN SISTEM INFORMASI PENGOLAHAN DATA PRODUKSI TBS (TANDAN BUAH SEGAR) KELAPA SAWIT BERBASIS MATERIAL REQUIREMENT PLANNING PADA PT. TANJUNG JAYA LESTARI LAMPUNG TENGAH
}

\author{
Zohan Fanani \\ Wiwin Susanty \\ Program Studi Sistem Informasi \\ Fakultas Ilmu Komputer, Universitas Bandar Lampung \\ Jl. Zainal Abidin Pagar Alam No. 26 \\ Labuhan Ratu Bandar Lampung 35142 \\ Email : Wien_adetha28@yahoo.com
}

\begin{abstract}
Analysis of Data Processing System Analysis Method to determine the production data processing FFB (fresh fruit bunches) Oil Palm at PT. Tanjung Jaya Lestari presented in this thesis. This analysis is an attempt to facilitate the ability to run the system using a variety of systems and one of them is Data Processing System Production at PT. Tanjung Jaya Lestari. "How to create a system of data processing applications for the production of FFB (fresh fruit bunches) of oil palm in the PT. Tanjung Jaya Lestari so it can more quickly and accurately? " At this time, perform data processing in the production of the production is still done by recording in the general ledger. This resulted in the frequent occurrence of errors and duplication of data pose serious problems. The objective of this paper is to describe, illustrate, and report the results of research carried out and provide solutions to problems that are found to facilitate the processes performed during data processing FFB production sawit.penelitian flashing this gives an insight and direct experience in the world work, so that students can integrate theory and practice acquired in the lecture bench with the reality on the ground.
\end{abstract}

Keyword : Analysis of Data Processing System.

\section{PENDAHULUAN}

\subsection{Latar Belakang}

Seiring dengan meningkatnya kebutuhan organisasi dan perusahaan dalam mengatur dan mengolah data untuk kegiatan oprasionalnya yang semakin komplek pada saat sekarang ini maka tentu saja dibutuhkan sebuah sistem sebuah sistem dan manajemen pengolahan data yang memiliki tingkat efektifitas dan efisien tinggi. Terlebih dengan perkembangan teknologi saat ini, semua kebutuhan akan datadata suatu organisasi atau perusahaan juga harus tersaji secara up-to-date, terintregitas, aman dan tentu saja sesuai dengan kebutuhan pengguna. Sistem yang dibangun haruslah mampu menyajikan data-data yang dibutuhkan dan tentu saja memiliki hubungan yang jelas antara data yang tersedia denagn pengguna yang membutuhkannya. Dengan demikian proses pengolahan data dapat dilakukan dengan efektif dan efisien.

PT. Tanjung Jaya Lestari Lampung Tengah merupakan salah satu komoditas pengolahan perkebunan kelapa sawit. PT. Tanjung Jaya Lestari Lampung Tengah beralamatkan di Kampung Tanjung Jaya Lampung Tengah yang berdiri pada tahun 1994. Luas perkebunan kelapa sawit sekitar $1.320 \mathrm{Ha}$.

Berdasarkan penelitian yang dilakukan di PT. Tanjung Jaya Lestari Lampung Tengah dalam menangani permasalahan khususnya pengolahan data produksi TBS (Tandan Buah Segar) berdasarkan pengolahan PKS (Pengolahan Kelapa Sawit) dan PIS (Pengolahan Inti Sawit), Buah yang diolah berupa kelapa sawit. Masalah ini ditangani oleh bagian Kantor DO (Deverly Order), Karena terlalu banyaknya data yang diinput dan output setiap harinya, sehingga sering terjadi kesalahan perhitungan antara data pengolahan PKS dan PIS untuk diinputkan ke dalam laporan produksi TBS maka sering terjadi penumpukan jadwal produksi yang sebelumnya belum selesai pada waktu yang dijadwalkan . Laporan produksi TBS juga sering terjadi keterlambatan dan duplikasi data, disebabkan belum menggunakan komputerisasi dan pencatatannya masih menggunakan buku besar.

Dari permasalahan tersebut dapat diatasi salah satunya dengan membuat sebuah Perancangan Sistem Pengolahan Data Produksi TBS (Tandan Buah Segar) kelapa sawit dengan menggunakan komputer yang dilengkapi software yang 
lengkap. Metode MRP (Material Requirement Planning) yaitu teknik yang digunakan untuk mengatasi masalah penjadwalan produksi yang sering bermasalah Sehingga tidak terjadi kesalahan dalam penjadwalan proses produksi dan laporan produksi TBS serta memberikan kemudahan dalam pengarsipan dan akan lebih efektif dari segi waktu pemprosesan laporan produksi TBS kelapa sawit berdasarkan data PKS dan PIS.

\subsection{Identifikasi Masalah}

Permasalahan - permasalahan yang dihadapi oleh PT. Tanjung Jaya Lestari yang berkaitan dengan pengolahan data produksi TBS kelapa sawit berdasarkan PKS dan PIS antara lain:

a. Penjadwalan produksi pengolahan kelapa sawit yang belum terstruktur, sehingga terjadi kesalahan atau ketelambatan proses produksi kelapa sawit dan pengolahan data produksi.

b. Pemanfaatan waktu yang kurang efektif, apabila terjadi kesalahan atau terjadi duplikasi data maka harus dilakukan perubahan pada arsip sehingga memerlukan waktu yang lama untuk melakukan perubahan pada arsip.

\subsection{Rumusan Masalah}

Masalah yang diteliti adalah proses pengolahan data produksi TBS kelapa sawit berdasarkan pengolahan PKS dan PIS pada PT. Tanjung Jaya Lestari, masalah tersebut dibahas untuk memberikan kemudahan dalam proses penjadwalan produksi dan laporan produksi TBS pada PT. Tanjung Jaya Lestari dan akan dicari penyelesainnya oleh penulis dalam penulisan tugas akhir ini, sehingga dapat dirumuskan masalah sebagai berikut :

Bagaimana membuat sistem aplikasi untuk pengolahan data produksi TBS (Tandan Buah Segar) kelapa sawit pada PT. Tanjung Jaya Lestari sehingga dapat lebih cepat dan akurat?

\subsection{Batasan Masalah}

Agar tidak menyimpang dan dapat berjalan sesuai dengan tujuannya, maka penulis membatasi pokok permasalahan hanya mengenai masalah pada sistem aplikasi pengolahan data produksi TBS kelapa sawit pada PT. Tanjung Jaya Lestari Berbasis Material Requirement Planning.

\subsection{Tujuan Penelitian dan Manfaat Penelitian}

\section{a. Tujuan penelitian}

Mencari data-data yang berkaitan dengan permasalah yang ditemukan, kemudian data-data yang diperoleh digunakan sebagai bahan pertimbangan dalam merancang aplikasi mengenai pengolahan data produksi TBS kelapa sawit berbasis Material Requirement Planning pada PT. Tanjung Jaya Lestari Lampung Tengah.

\section{b. Manfaat Penelitian}

1. Menambah wawasan dan kemampuan penulis dalam mempersiapkan diri untuk memasuki dunia kerja yang nyata dan penuh persaingan.

2. Memberikan masukan kepada PT. Tanjung Jaya Lestari untuk mempermudah dalam membuat proses penjadwalan produksi dan proses laporan data produksi TBS kelapa sawit pada PT. Tanjung Jaya Lestari Lampung Tengah.

\subsection{Pengertian Perancangan}

Perancangan adalah suatu kegiatan yang memiliki tujuan untuk mendesign sistem baru yang dapat menyelesaikan masalahmasalah yang dihadapi perusahaan yang diperoleh dari pemilihan alternatif sistem yang terbaik.

(Al-Bahra Bin Ladjamudin, 2005 : 59)

\subsection{Konsep Dasar sistem \\ 2.2.1 Definisi Sistem}

Pada prinsipnya, setiap sistem selalu terdiri atas elemen:

a. Objek, yang dapat berupa bagian, elemen, ataupun variabel. Ia dapat benda fisik, abstrak, ataupun keduanya sekaligus; tergantung kepada sifat sistem tersebut.

b. Atribut, yang menentukan kualitas atau sifat kepemilikan sistem dan objeknya.Hubungan internal, di antara objek-objek di dalamnya.

c. Lingkungan, tempat di mana sistem berada.

Sistem adalah kumpulan dari elemen-elemen yang berinteraksi untuk mencapai suatu tujuan tertentu. (Jogiyanto, HM, 2005 : 2)

\subsubsection{Karakteristik Sistem}

Sistem memiliki karakteristik atau sifat-sifat tertentu, yang mencirikan bahwa hal tersebut bisa dikatakan sebagai suatu sistem. Adapun karakteristik yang dimaksud adalah sebagai berikut : 
a. Komponen Sistem (Components)

Suatu sistem terdiri dari sejumlah komponen yang saling berinteraksi, yang bekerja sama membentuk satu kesatuan. Komponen-komponen sistem tersebut dapat berupa suatu bentuk subsistem. Setiap subsistem memiliki sifat-sifat dari sistem yang menjalankan suatu fungsi tertentu dan mempengaruhi proses sistem secara keseluruhan. Suatu sistem dapat mempunyai sistem yang lebih besar, yang disebut dengan Supra sistem.

b. Batasan Sistem (Boundary)

Ruang lingkup sistem merupakan daerah yang membatasi antara sistem dengan sistem yang lainnya atau sistem dengan lingkungan luarnya. Batasan sistem ini memungkinkan suatu sistem dipandang sebagai satu kesatuan yang tidak dapat dipisah-pisahkan.

c. Lingkungan Luar Sistem (Environtment)

Bentuk apapun yang ada di luar ruang lingkup atau batasan sistem yang mempengaruhi operasi sistem tersebut disebut dengan lingkungan luar sistem. Lingkungan luar sistem ini dapat menguntungkan dan dapat juga merugikan sistem tersebut. Lingkungan luar yang menguntungkan merupakan energi bagi sistem tersebut, yang dengan demikian lingkungan luar tersebut harus selalu dijaga dan dipelihara. Sedangkan lingkungan luar yang merugikan harus dikendalikan, karena kalau tidak maka akan mengganggu kelangsungan hidup sistem tersebut.

d. Penghubung Sistem (Interface)

Sebagai media yang menghubungkan sistem dengan subsistem yang lain disebut dengan penghubung sistem atau interface. Penghubung ini memungkinkan sumber-sumber daya mengalir dari satu subsistem ke subsistem yang lain. Keluaran suatu subsistem akan menjadi masukan untuk subsistem yang lain dengan melewati penghubung. Dengan demikian terjadi suatu integrasi sistem yang membentuk satu kesatuan.

e. Masukan Sistem (Input)
Energi yang dimasukan ke dalam sistem disebut masukan sistem, yang dapat berupa pemeliharaan (Maintenance input) dan sinyal (Signal input). Sebagai contoh, di dalam suatu unit sistem komputer, "program" adalah maintenance input yang digunakan untuk mengoperasikan komputer sementara "data" adalah signal input yang akan diolah menjadi informasi.

f. Keluaran Sistem (Output)

Hasil dari energi yang diolah dan diklasifikasikan menjadi keluaran yang berguna. Keluaran ini merupakan masukan bagi subsistem yang lain. Seperti contoh sistem informasi, keluaran yang dihasilkan adalah informasi, yang mana informasi ini dapat digunakan sebagai masukan untuk pengambilan keputusan atau halhal lain yang merupakan input bagi subsistem lainnya.

g. Pengolah Sistem (Proses)

Suatu sistem dapat mempunyai suatu proses yang akan mengubah masukan menjadi keluaran. Sebagai contoh, sistem akuntansi. Sistem ini akan mengolah data transaksi menjadi laporan-laporan yang dibutuhkan oleh pihak manajemen.

h. Sasaran Sistem (Objective)

Suatu sistem memiliki tujuan dan sasaran yang pasti dan bersifat deterministik. Kalau suatu sistem tidak memiliki sasaran, maka operasi sistem tidak ada gunanya. Suatu sistem dikatakan berhasil bila mengenai sasaran atau tujuan yang telah direncanakan.

(Tata Sutabri, SIM, 2005 : 11-12)

\subsubsection{Model Umum Suatu Sistem}

Model umum suatu sistem adalah terdiri atas masukan (input), pengolah (process), dan keluaran (output). (Tata Sutabri, SIM, 2005 : 11)

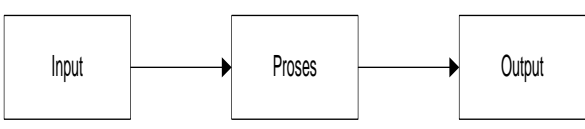

Gambar 2.1.3 Model umum suatu sistem 


\subsection{Konsep Dasar Data dan Informasi 2.3.1 Definisi Data}

Data adalah kenyataan yang menggambarkan suatu kejadian-kejadian dan kesatuan nyata. (Tata Sutabri, SIM, 2005 : 16). Menurut Gordon B. Davis dalam bukunya Management Information System : Conceptual Foundations, Structures, and Development menyebut data sebagai bahan mentah dari informasi, yang dirumuskan sebagai sekelompok lambanglambang tidak acak yang menunjukkan jumlah atau tindakan atau hal-hal lain. (Wahyono, Teguh, 2004 : 2)

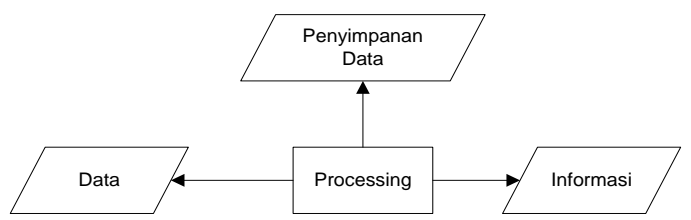

Gambar 2.2.1 Pemrosesan Data

\subsubsection{Definisi Informasi}

Informasi adalah data yang diolah menjadi bentuk yang lebih berguna dan lebih berarti bagi yang menerimanya. (Jogiyanto, HM, 2005 : 8). Menurut Gordon B. Davis, informasi adalah data yang telah diubah menjadi bentuk yang berguna bagi penerimanya dan nyata, berupa nilai yang dapat dipahami di dalam keputusan sekarang maupun masa depan. (Wahyono, Teguh, 2004 : 3). Sedangkan menurut Robert N. Anthony dan John Dearden di dalam buku Management Control System, informasi sebagai suatu kenyataan, data, item yang menambah pengetahuan bagi penggunanya. (Wahyono, Teguh, 2004 : 3)

\subsection{Konsep Dasar Sistem Informasi \\ 2.4.1 Definisi Sistem Informasi}

Sistem informasi adalah suatu sistem didalam suatu organisasi yang mempertemukan kebutuhan pengolahan transaksi harian, pendukung operasi, bersifat menejerial, dan kegiatan strategi dari suatu organisasi dan menyediakan pihak luar tertentu dengan laporan-laporan yang diperlukan.

(Jogiyanto, HM, 2005 : 8)

Sistem informasi adalah suatu cara tertentu untuk menyediakan informasi yang dibutuhkan oleh organisasi dan organisasi bisnis untuk beroperasi dengan cara yang sukses dan cara yang menguntungkan. (Wahyono, Teguh, 2004 : 17)

\subsubsection{Komponen Sistem Informasi}

Stair (1992) menjelaskan bahwa Sistem Informasi berbasis komputer (CBIS) dalam suatu organisasi terdiri dari komponenkomponen berikut :

a. Perangkat keras

Perangkat keras komponene untuk melengkapi kegiatan memasukkan data, memproses data, dan keluaran data.

b. Perangkat Lunak Program dan instruksi yang diberikan ke komputer.

c. Basis Data

Kumpulan data dan informasi yang diorganisasikan sedemikian rupa sehingga mudah diakses pengguna sistem informasi.

d. Telekomunikasi

Komunikasi yang menghubungkan antara pengguna sistem dengan sistem komputer secara bersama-sama kedalam suatu jaringan kerja yang aktif.

e. Manusia

Personel dari sistem informasi meliputi manajer, analisis, programer dan operator, serta bertanggung jawab terhadap perawatan sistem.

( Hanif Al Fatta, 2007 : 9)

\subsection{Database}

Agar lebih bermanfaat data harus diolah ke dalam suatu file database. Menurut Jogiyanto HM [ 2005 ], "Database merupakan kumpulan data yang saling berhubungan satu dengan lain tersimpan di perangkat keras computer dan digunakan perangkat lunak untuk memanipulasinya. Data perlu disimpan di dalam database untuk keperluan penyediaan informasi lebih lanjut".

\subsubsection{Istilah dalam Database}

Terdapat banyak istilah yang digunakan database seperti entity, file, record, dan field. Definisi dari masing-masing istilah tersebut sebagai berikut [ Jogiyanto HM, 2005 ] :

a. Field

Menggambarkan suatu atribut dari record yang menunjukan suatu item dari data.

b. Record

Kumpulan elemen-elemen atau field yang saling berkaitan dan disusun untuk membentuk file.

c. File

Kumpulan-kumpulan sejenis yang saling berhubungan dan yang saling bersamaan file. Berkas adalah kumpulan record-record sejenis yang mempunyai panjang yang sama, atribut 
yang sama, namun berbeda-beda data valuenya.

d. Entity

Tempat kejadian atau konsep informasinya direkam.

\subsection{MySQL}

$S Q L$ adalah bahasa standar yang digunakan untuk mengakses database server dalam konteks bahasa $S Q L$. Pada umumnya informasi tersimpan dalam tabel-tabel yang secara logika merupakan struktur dua dimensi yang terdiri atas baris-baris data yang berada dalam satu atau lebih kolom. Baris pada tabel disebut sebagai instance dalam data, sedangkan kolom disebut sebagai attribute atau field. Keseluruhan table itu dihimpun dalam satu kesatuan yang disebut database.

\subsection{Pengolahan Data}

Menurut Jogianto HM, 2005, pengolahan data adalah manipulasi dari bantuk data kedalam bentuk yang lebih berguna atau berarti yaitu berupa suatu informasi.

Menurut Kamus Besar Bahasa Indonesia [Edisi Ketiga, 2005], Pengolahan data adalah proses atau pembuatan atau cara mengolah sesuatu kedalam bentuk yang lebih berarti.

\subsection{Produksi TBS ( Tandan Buah Segar)}

"Produksi TBS adalah proses pengolahan hasil buah kelapa sawit yang masih segar untuk dijadikan minyak CPO (Crude Palm Oil) yang baik". (Kamus Besar Bahasa Indonesia, 2005)

\subsection{Landasan Teori \\ 2.9.1 Definisi MRP}

Perencaaan kebutuhan material (MRP) dapat didefinisikan sebagai suatu teknik atau set prosedur yang sistematis untuk penentuan kuantitas serta waktu dalam proses perencanaan dan pengendalian item barang (komponen) yang tergantung pada item-item tingkat (level) yang lebih tinggi (dependent demand). Ada 4 kemempuan yang menjadi ciri utama dari sistem MRP yaitu :

1. Mampu menentukan kebutuhan pada saat yang tepat.

2. Membentuk kebutuhan minimal untuk setiap item.

3. Menentukan pelaksanaan rencana pemesanan.

4. Menentukan penjadwalan ulang atau pembatalan atas jadwal yang sudah direncanakan.
Dalam produksi, MRP dianggap sebagai pandangan hidup dalam manajemen bisnis manufaktur, joseph orlicky adalah orang yang mempopulerkan. (M. Syamsul Ma'arif, 2003:324).

\subsection{Metodologi Penelitian}

Dalam penulisan laporan skripsi ini, penulis menggunakan metode penelitian deskriptif, yaitu metode penelitian yang membuat gambaran mengenai permasalahan yang telah diidentifikasi oleh penulis, dimana objek yang diteliti dijelaskan dari sudut pandang penulis.

\subsection{Metode Pengumpulan Data \\ 3.2.1 Observasi}

Observasi atau pengamatan merupakan salah satu teknik pengumpulan fakta/data yang cukup efektif. Observasi adalah pengamatan langsung suatu kegiatan yang sedang dilakukan. Pada waktu melakukan observasi, analis sistem dapat ikut juga berpartisipasi atau hanya mengamati saja orang-orang yang sedang melakukan suatu kegiatan tertentu yang di observasi. Melalui teknik observasi ini, penulis mengadakan penelitian di PT. Tanjung Jaya Lestari di Lampung Tengah dan mengumpulkan data tentang produksi TBS kelapa sawit.

\subsubsection{Wawancara (Interview)}

Wawancara telah diakui sebagai teknik pengumpulan data atau fakta yang penting dan banyak dilakukan dalam pengembangan sistem informasi. Wawancara memungkinkan analis sistem sebagai pewawancara untuk mengumpulkan data secara tatap muka langsung dengan orang yang diwawancarai. Wawancara dilakukan langsung dengan Kepala Bagian Deverly Order (DO) yang menangani data produksi TBS, bagian PKS dan PIS sampai menjadi CPO dan mengajukan pertanyaan mengenai data pengolahan produksi TBS.

\subsubsection{Dokumentasi}

Dokumentasi adalah suatu teknik pengumpulan data dengan cara melakukan pencatatan terhadap data-data yang dibutuhkan. Dengan teknik pengumpulan data ini, penulis mendapatkan informasi tentang struktur organisasi dan informasi tentang perencanaan persediaan barang elektronik yang sedang berjalan pada PT. Tanjung Jaya Lestari di Lampung Tengah.

\subsection{Metode Analisis Sistem}


Analisis sistem adalah kegiatan untuk melihat siklus sistem yang ada atau sistem yang berjalan saat ini di PT. Tanjung Jaya Lestari Lampung Tengah. Untuk menjelaskan analisis sistem yang telah diteliti, maka penulis mencoba untuk menjelaskan dengan menggunakan alat-alat bantu modeling dibawah ini, yaitu:

\subsubsection{Analisa Sistem Berjalan}

Berikut akan dijelaskan tentang hasil analisa dari sistem pengolahan data produksi TBS yang berjalan pada PT. Tanjung Jaya Lestari Lampung Tengah dapat dijelaskan sebagai berikut :

1. Dimulai dari Bagian Pengolahan Kelapa Sawit mengolah TBS menjadi minyak sawit dan inti sawit (brondolan), jika ada TBS yang diterima.

2. Setelah itu mencatat hasil pengolahan TBS ke dalam data produksi minyak sawit dan inti sawit dua rangkap, rangkap pertama diarsipkan dan rangkap kedua diberikan ke kantor DO. Lalu minyak sawit dan inti sawit diberikan kepada Bagian Laboratorium.

3. Bagian Laboratorium meneliti minyak sawit dan inti sawit untuk mengetahui mutu bahan baku hasil pengolahan. setelah diteliti minyak sawit dan inti sawit diberikan ke Bagian Pengolahan Inti Sawit.

4. Bagian Pengolahan Inti Sawit mengolah kembali minyak sawit dan inti sawit yang sudah diteliti, menjadi minyak inti sawit (CPO) dan ampasnya menjadi bungkil inti sawit.

5. Kemudian Bagian Pengolahan Inti Sawit mencatat hasil pengolahan ke dalam data Produksi Minyak inti sawit dan bungkil inti sawit menjadi dua rangkap, rangkap pertama diarsipkan sedangkan rangkap kedua akan diberikan kepada Kantor DO.

6. Kantor DO mengecek kebenaran data pengolahan produksi dari Bagian Pengolahan Kelapa Sawit dan Pengolahan Inti Sawit. Jika data benar, maka kantor DO membuatkan laporan pengolahan produksi TBS menjadi dua rangkap, rangkap pertama diberikan ke Manajer untuk ditandatangani,

7. Sedangkan rangkap yang kedua dibuatkan laporan pengiriman CPO yang sudah ditandatangani, dilakukan dengan cara mengirimkan CPO sekitar
100 ton untuk menghindari pembusukan dan penuhnya CPO. laporan pengiriman $\mathrm{CPO}$ yang sudah ditandatangani akan diberikan ke Unit Usaha lain yang sudah terkait dengan PT.Tanjung Jaya Lestari.

8. Sedangkan jika ada data yang salah, maka akan diubah datanya ke Bagian Pengolahan Kelapa Sawit dan Pengolahan Inti Sawit.

9. Manajer menandatangani Laporan pengolahan produksi TBS dan diarsipkan

\subsubsection{Diagaram Alir Sistem Penolahan Data Produksi TBS Kelapa Sawit}

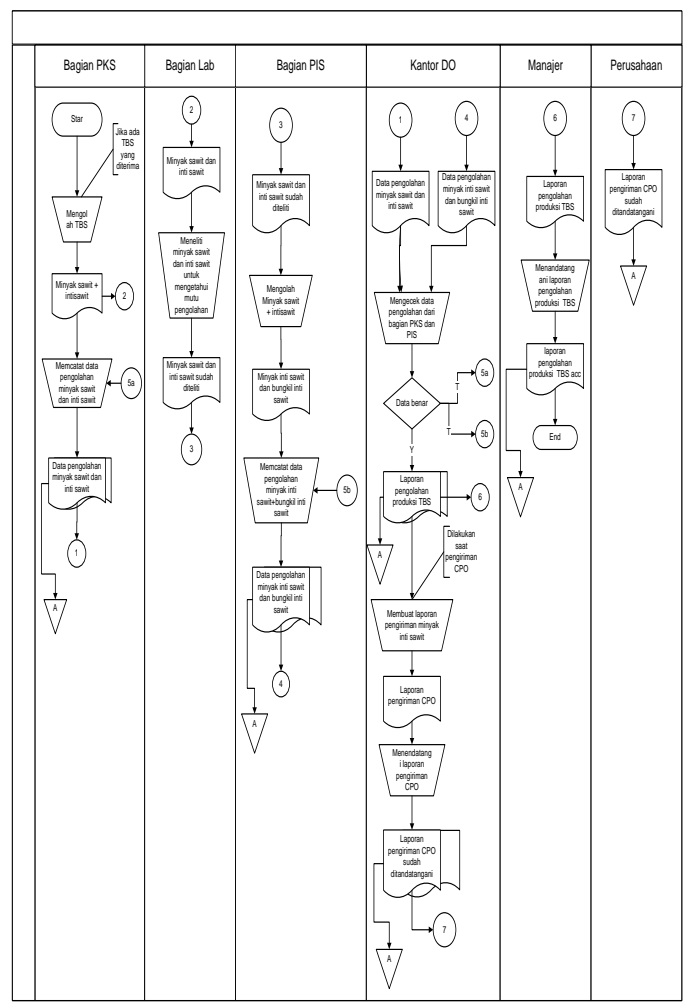

Gambar 3.3.2 Diagram Alir Dokumen sistem yang sedang berjalan

\subsubsection{Analisa Kebutuhan}

Dari analisis masalah yang ada maka diperlukan kebutuhan yang nantinya akan digunakan dalam pemakaian dan pengembangan sistem yaitu :

a) Perangkat Keras (Hardware) Sistem yang digunakan :

1. PC dengan Prosesor Intel Dual Core 2,00GHz

2. Memori $1 \mathrm{~GB}$ 
3. Partisi hard disk dengan ruang yang cukup untuk komponen yang diinstal (Sekitar 160GB). Semakin banyak komponen, semakin banyak komponen yang diinstal, semakin banyak ruang yang dibutuhkan.

4. Monitor Samsung 17"

5. DVD-Rom Drive

6. Printer

7. Mouse optik standar PS2 atau USB

8. Keyboard standar 101 key

b) Perangkat Lunak (Software) Sistem yang digunakan :

1) Sistem Operasi Windows 7 Ultimate

2) Netbeans 6.9 java editor Proses pembuatan form, gambar, teks, dan coding pembuatan aplikasi dilakukan dengan menggunakan Netbeans 6.9.

3) $M y S Q L$

$S Q L$ adalah bahasa standar yang digunakan untuk mengakses database server dalam konteks bahasa $S Q L$. Pada umumnya informasi tersimpan dalam tabel-tabel yang secara logika merupakan struktur dua dimensi yang terdiri atas baris-baris data yang berada dalam satu atau lebih kolom. Baris pada tabel disebut sebagai instance dalam data, sedangkan kolom sering disebut sebagai attribute atau field. Keseluruhan tabel itu dihimpun dalam satu kesatuan yang disebut database.

\section{HASIL DAN PEMBAHASAN}

\subsection{Sejarah Singkat PT. Tanjung Jaya Lestari Lampung Tengah}

Teknologi Informasi merupakan cabang ilmu pengetahuan yang sangat di gemari semua orang saat ini. Hal ini timbul karena perkembangan peradaban manusia yang menuntut setiap individunya memiliki kemampuan dalam bidang teknologi informasi ini.

PT. Tanjung Jaya Lestari Lampung Tengah merupakan salah satu perusahaan yang bergerak dibidang pengolahan kelapa sawit yang didirikan oleh Bpk. Tedy Santoso yang mempunyai perkebunan kelepa sawit terluas di desa tanjung jaya. PT. Tanjung Jaya Lestari Lampung Tengah beralamatkan di Kampung Tanjung Jaya Kecamatan Bangunrejo Lampung Tengah yang berdiri pada tahun 1994.

PT. Tanjung Jaya Lestari mulanya hanya merupakan usaha yang beroperasi untuk mengolah kelapa sawit milik sendiri akan tetapi melihat dari masyarakat khususnya dari desa Tanjung Jaya dan wilayah lampung tengah yang mempunya banyak perkebunan sawit maka PT. Tanjung Jaya Lestari telah dibuka untuk umum sejak tahun 1997.

\subsection{Struktur Organisasi}

Struktur organisasi adalah bentuk kerjasama dalam mencapai tujuan yang telah ditetapkan sebelumnya. Struktur organisasi merupakan kerangka yang menunjukkan satuansatuan organisasi tentang tugas dan tanggung jawab yang telah ditentukan. Struktur organisasi akan tampak lebih jelas apabila dituangkan dalam bagan organisasi dan akan memberikan pengertian yang lebih jelas mengenai struktur organisasi PT. Tanjung Jaya Lestari Lampung Tengah dapat dilihat pada gambar berikut dibawah ini:
1. Perusahaan
2. Manajer
3. Kepala bagian Deverly Order
4. Bagian PKS
5. Bagian PIS
6. Bagian Laboratorium 
Berikut ini di gambarkan struktur organisasi yang ada pada PT. Tanjung Jaya Lampung Tengah.

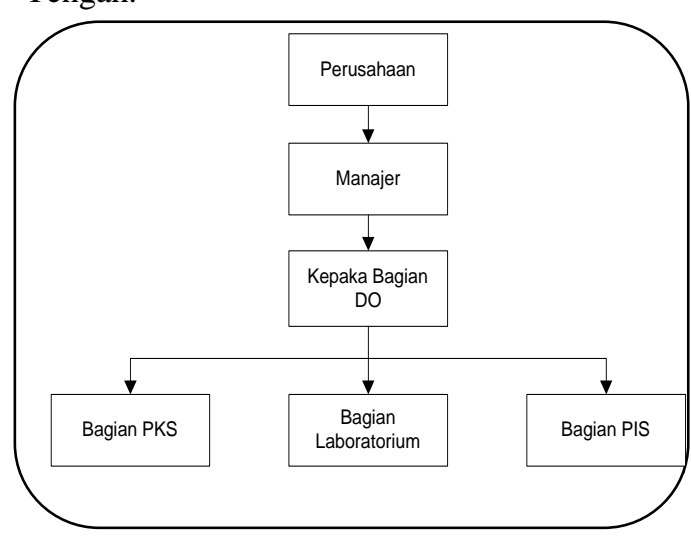

\subsection{Pembahasan Sistem Informasi Pengolahan Data Produksi TBS}

Berdasarkan hasil penelitian yang telah diterangkan pada Bab III maka penulis dapat menjelaskan sistem atau prosedur analisa sistem berjalan dari sistem pengolahan data produksi TBS kelapa sawit pada PT. Tanjung Jaya Lestari.

\subsubsection{Diagram UML}

\subsubsection{Use Case Diagram}

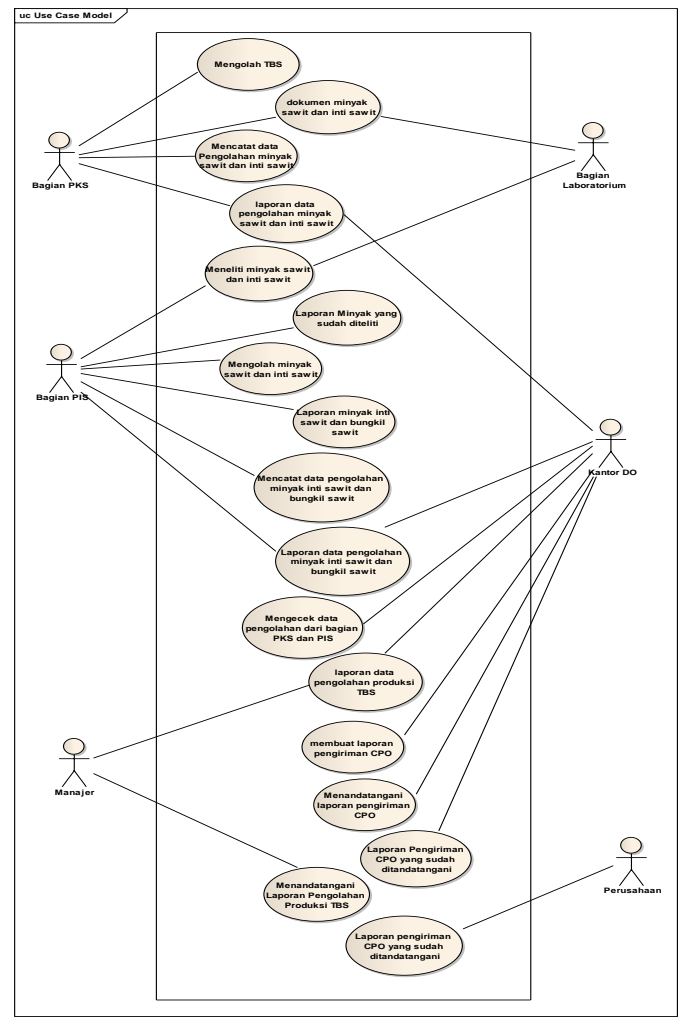

Gambar 4.3.1 Use Case Diagram Global Pengolahan Data Produksi TBS

\subsection{Class Diagram}

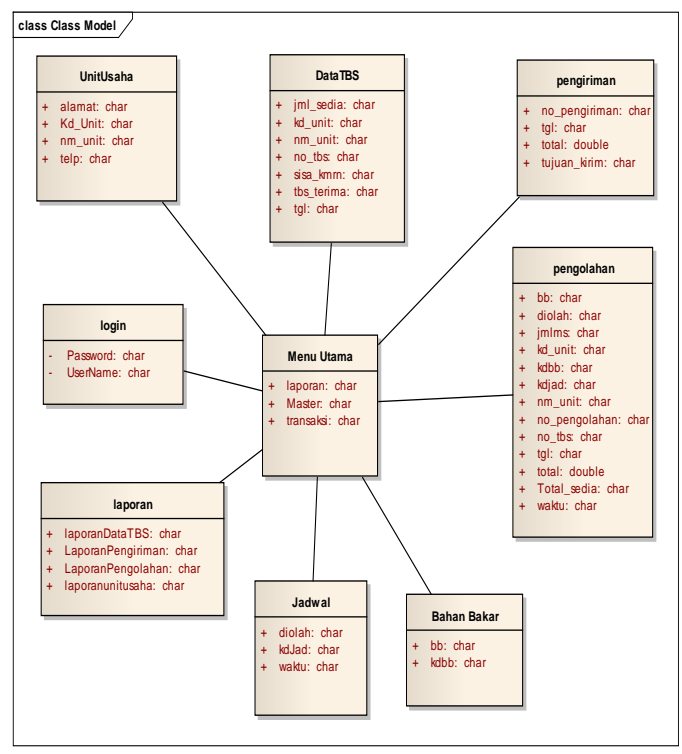

Gambar 4.3.2 Class Diagram Pengolahan Data Produksi TBS

\subsubsection{Relasi Anter Tabel}

4.3.3

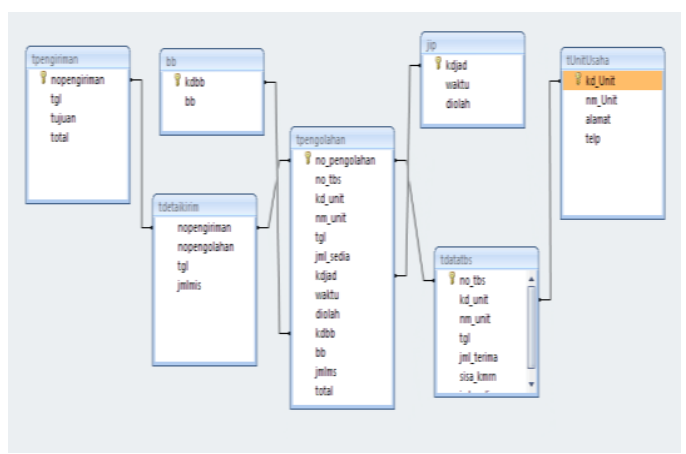

Gambar 4.5 Relasi Anter Tabel

\subsection{Hasil Interface Pengguna}

Berikut adalah beberapa tampilan antar muka pengguna untuk berinteraksi dengan sistem

\section{Form Login}

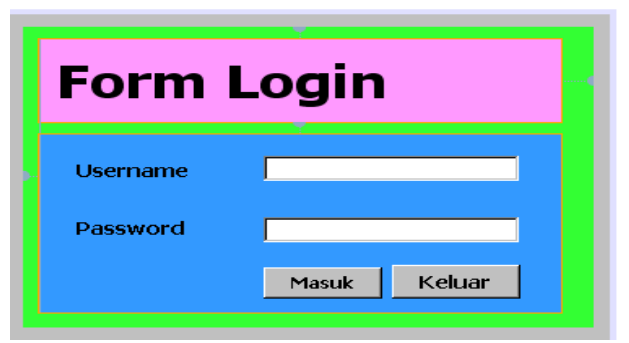

Form ini adalah tampilan awal pada saat membuka aplikasi, di form ini bagi pengguna 
bisa melakukan login pada saat akan masuk kedalam aplikasi pengolahan data

\section{Form Menu Utama}

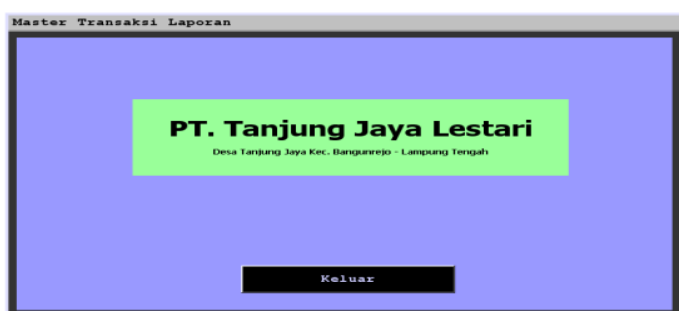

Gambar 4.7.2 Form Menu Utama

Form ini muncul ketika pengguna berhasil melakukan login, pada form ini terdapat menu yang dapat terhubung dengan form lainnya seperti Master, Transaksi dan laporan.

\section{Form Master Unit Usaha}

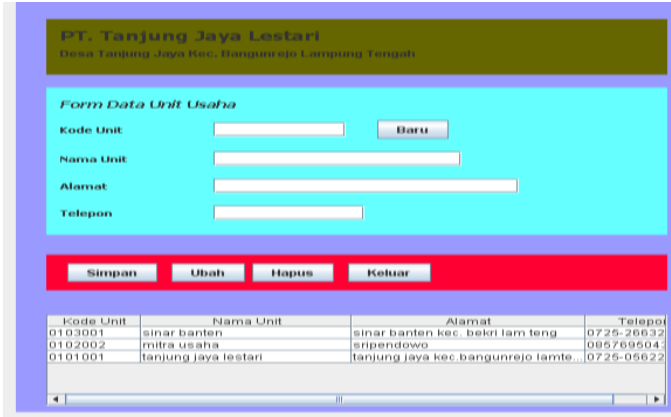

Form ini muncul ketika pada form menu utama memilih menu master, input data unit, form ini akan menyimpan data unit usaha.

\section{Form Master Data TBS}

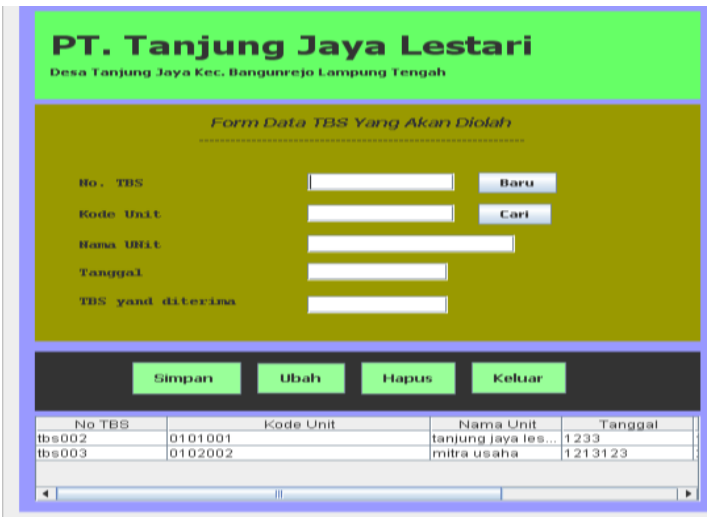

Gambar 4.7.4 Form Data TBS
Form ini juga terdapat pada menu master yang akan digunakan untuk meninput data TBS kelapa sawit yang akan diproduksi.

\section{Form Master JIP}

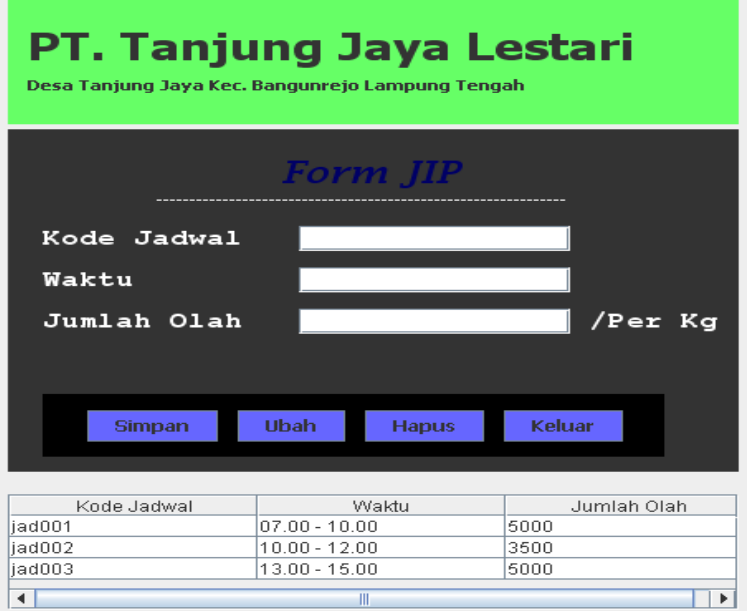

Gambar 4.7.5 Form JIP

\section{Form Master Bahan Bakar}

\section{PT. Tanjung Jaya Lestari}

Desa Tanjung Jaya Kec. Bangunrejo Lampung Tengah
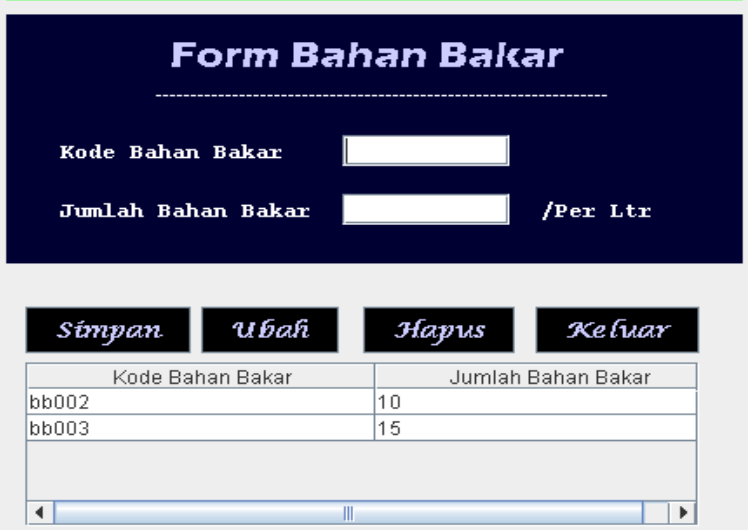

Gambar 4.7.6 Form Bahan Bakar 


\subsubsection{Form Transaksi Pengolahan}

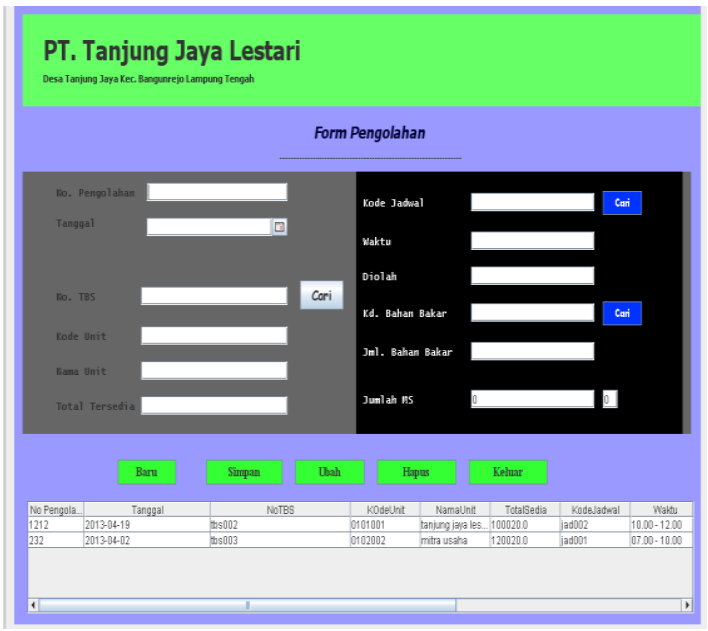

Gambar 4.7.7 Form Pengolahan

Form ini akan muncul pada saat user memilih menu transaksi pada form menu utama yang digunakan untuk menginputkan data pengolahan produksi.

\section{Form Transaksi Pengiriman}

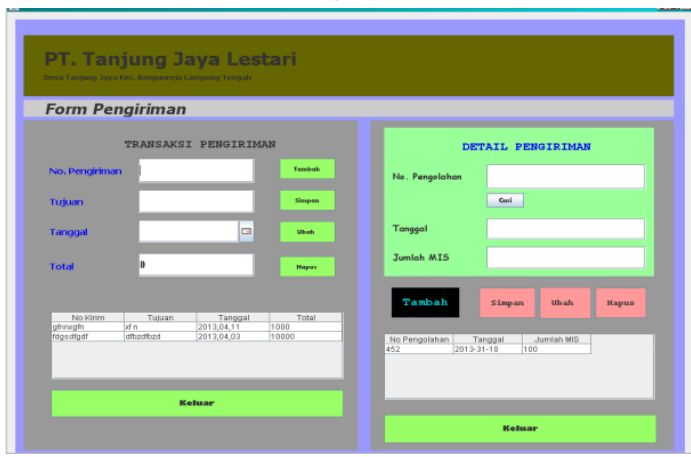

Gambar 4.7.8 Form Pengiriman

Form ini juga akan muncul ketika pengguna memilih menu transaksi pada menu utama yang digunakan untuk melakukan pengiriman CPO.

\section{Kesimpulan}

Setelah melakukan perancangan, pembuatan dan pengujian terhadap penerapan Sistem Pengolahan Data, maka didapat beberapa kesimpulan :

1. Penerapan Sistem Pengolahan Data dengan memanfaatkan Aplikasi untuk Pengolahan data dapat mempermudah kinerja dalam proses pengolahan data produksi pada PT. Tanjung Jaya Lestari.
2. Dengan adanya penerapan aplikasi Pengolahan Data ini, maka sistem produksi pada PT. Tanjung Jaya Lestari, dapat berguna sebagai solusi dari permasalahan yang ada.

\subsection{Saran}

Dalam rangka meningkatkan kinerja system dikemudian hari, maka berikut beberapa saran yang perlu dipertimbangkan

a) Upgrade perangkat keras yang baru agar lebih optimal di dalam proses pengolahan data produksi.

b) Diadakannya pelatihan paket perangkat lunak (software) kepada user dalam rangka meningatkan kinerja dan kecepatan di dalam proses pengolahan data produksi.

c) Diupayakan dapat mengoptimalkan dengan menggunakan aplikasi pengolahan data produksi TBS kelapa sawit yang telah dibuat.

\section{DAFTAR PUSTAKA}

1) Jogiyanto, HM, MBA, Ph.D. 2005. Analisis dan Desain Sistem Informasi. ANDY. Yogyakarta.

2) Sutabri, Tata, S.Kom, MM. 2005. Sistem Informasi Manajemen. ANDY. Yogyakarta.

3) Wahyono, Teguh. 2004. Sistem Informasi (Konsep Dasar, Analis Desain Dan Implementasi). Graha ilmu. Yokyakarta.

4) Indrajit, Richardus E. 2003. Cara Penerapan MRP. Andy. Yokyakarta

5) Kristanto, H. 2002. Konsep Dan Perancangan Database. Andi Offset, Yokyakarta

6) Modul NIIT, Object Oriented Analysis and Desaign Using UML.

7) [http://kamusbahasaindonesia.org/].

8) http://digilib.ittelkom.ac.id/index.php? option $=$ com_content $\&$ view $=$ article $\&$ id $=962: \mathrm{mrp}$-material-requirementplanning\&catid $=25$ :industri $\&$ Itemid $=1$ 4

9) http://dodogusmao.wordpress.com/201 0/07/28/material-requirementplanning/

10) http://staff.ui.ac.id/internal/131472309/ material/Pengepro-4-MRP-2008.pdf 